University of South Florida

DIGITAL COMMONS

Digital Commons @ University of

@ UNIVERSITY OF SOUTH FLORIDA

South Florida

Government and International Affairs Faculty

Publications

Government and International Affairs

4-1-2006

\title{
Iran's Policy Towards Afghanistan
}

Mohsen M. Milani

University of South Florida, Milani@usf.edu

Follow this and additional works at: https://digitalcommons.usf.edu/gia_facpub

Part of the International and Area Studies Commons

\section{Scholar Commons Citation}

Milani, Mohsen M., "Iran's Policy Towards Afghanistan" (2006). Government and International Affairs

Faculty Publications. 106.

https://digitalcommons.usf.edu/gia_facpub/106

This Article is brought to you for free and open access by the Government and International Affairs at Digital Commons @ University of South Florida. It has been accepted for inclusion in Government and International Affairs Faculty Publications by an authorized administrator of Digital Commons @ University of South Florida. For more information, please contact digitalcommons@usf.edu. 


\section{The Middle East Journal}

Iran's Policy Towards Afghanistan

Author(s): Mohsen M. Milani

Source: Middle East Tournal, Vol. 60, No. 2 (Spring, 2006), pp. 235-256

Published by: Middle East Institute

Stable URL: http://www.jstor.org/stable/4330248

Accessed: 20/05/2011 12:37

Your use of the JSTOR archive indicates your acceptance of JSTOR's Terms and Conditions of Use, available at http://www.jstor.org/page/info/about/policies/terms.jsp. JSTOR's Terms and Conditions of Use provides, in part, that unless you have obtained prior permission, you may not download an entire issue of a journal or multiple copies of articles, and you may use content in the JSTOR archive only for your personal, non-commercial use.

Please contact the publisher regarding any further use of this work. Publisher contact information may be obtained at http://www.jstor.org/action/showPublisher?publisherCode=mei.

Each copy of any part of a JSTOR transmission must contain the same copyright notice that appears on the screen or printed page of such transmission.

JSTOR is a not-for-profit service that helps scholars, researchers, and students discover, use, and build upon a wide range of content in a trusted digital archive. We use information technology and tools to increase productivity and facilitate new forms of scholarship. For more information about JSTOR, please contact support@ jstor.org.

Middle East Institute is collaborating with JSTOR to digitize, preserve and extend access to Middle East Journal. 


\title{
Iran's Policy Towards Afghanistan
}

\author{
Mohsen M. Milani
}

Since 1979, Iran's objectives in Afghanistan have changed as Afghanistan's domestic landscape changed. Still, Iran has consistently sought to see a stable and independent Afghanistan, with Herat as a buffer zone and with a Tehranfriendly government in Kabul, a government that reflects the rich ethnic diversity of the country. Toward those and other goals, Iran has created "spheres of influence" inside Afghanistan. During the Soviet occupation (1979-88), Iran created an "ideological sphere of influence" by empowering the Shi' ites. Iran then created a "political sphere of influence" by unifying the Dari/Persianspeaking minorities, who ascended to power. Iranian policies added fuel to the ferocious civil war in the 1990s. Astonishingly slow to recognize the threat posed by the Taliban, Iran helped create a "sphere of resistance" to counter the "KabulIslamabad-Riyadh" axis by supporting the Northern Alliance. Since the liberation of Afghanistan, Iran has also established an "economic sphere of influence" by engaging in the reconstruction of Afghanistan. Today, Iran's goals are to pressure the Afghan government to distance itself from Washington, and for Iran to become the hub for the transit of goods and services between the Persian Gulf and Afghanistan, Central Asia, India, and China. While Iran has been guilty of extremism and adventurism in some critical aspects of its foreign policy, its overall Afghan policy has contributed more to moderation and stability than to extremism and instability.

$\mathrm{T}$ here is considerable consensus among experts that Iran has played an important role in the tumultuous events in Afghanistan since the brutal occupation of that country by the Soviet Army in 1979. What is being debated is the exact impact, and consequences, of that role. What follows is a contribution to this lingering debate.

Since its founding, the Islamic Republic of Iran has developed a security-centered, two-layered foreign policy to expand and protect its interests as well as to neutralize the perceived threat posed by the United States, a threat Tehran has consistently regarded as existential. The foundation of this foreign policy is based on the

Mohsen M. Milani is a Professor of Politics and Chair of the Department of Government and International Affairs at the University of South Florida in Tampa, Florida (http:www.cas.usf.edu.edu/GIA/ milani_mohsen.htm). Different parts of this article were presented to the National Defense University, the Woodrow Wilson International Center for Scholars in Washington, and Stanford University. Many thanks to Drs. Judi Yaphe, Halah Esfandiyari, and Robert Crews for inviting me to their respective institutions. I am grateful to Mr. Eric Wolters, my talented Graduate Assistant, for his valuable assistance, and to Professors Richard Norton, Seyyed Vali Nasr, and Dr. Marvin Weinbaum for reading the entire article and making insightful suggestions. The author is solely responsible for the contents of the article. 
pragmatic recognition of the existence of a colossal power differential, particularly in the military arena, between Iran and the US. Iran has persistently sought not to allow hostile bilateral relations to descend into a military confrontation between the two countries. Additionally, in an effort to build an effective deterrent against the US, Iran has developed unconventional and asymmetric strategies in both its military and foreign policy arenas. One such strategy is to create "spheres of influence," buffer zones, as well as a web of both informal and formal, underground and open organizations around Iran's troubled neighborhood, and beyond its borders. This strategy allows Iran to project its power and enhance its interests, support Islamic movements, create a defensive and sometimes invisible wall outside its borders, and position its friendly forces and proxies beyond its borders against those who threaten its own survival. In its policy toward Afghanistan since 1979, Iran has employed the most important elements of this strategy and has created different kinds of "spheres of influence" in that country.

\section{CREATING AN IDEOLOGICAL SPHERE OF INFLUENCE, 1979-88}

In July of 1973, Afghan King Zaher Shah (1933-73) was overthrown in a coup staged by Muhammad Daud Khan, who then demolished the monarchy, established a republic, and began flirting with Moscow. ${ }^{1}$ For Muhammad Reza Shah Pahlavi of Iran (1941-79), the coup was as an ominous sign of Soviet machinations to dominate Afghanistan. At first, he contemplated organizing a rebellion from Western Afghanistan to restore the monarchy. ${ }^{2}$ He quickly abandoned the plan, however, largely because he viewed Zaher Shah to be disgustingly timid and inept, even though he reportedly provided limited financial support for the exiled king in Italy. ${ }^{3} \mathrm{He}$ ultimately opted to appease Daud by offering Kabul a lucrative assistance package in $1974 .{ }^{4}$ Ironically, as Daud was moving closer to Iran, he was overthrown by a coup in April of 1978, and nine months later, Muhammad Reza Shah, too, was dethroned by a popular revolution that elevated Ayatollah Rouhollah Khomeini to power. ${ }^{5}$

\footnotetext{
1. See Hafizullah Emadi, State, Revolution and Superpowers in Afghanistan (New York: Praeger, 1990).

2. Assadollah Alam, Khofteghohay-e Man Ba Shah [My Conversations with the Shah] Vol. II, (Tehran: Tarh-e Nou, 1992), pp. 490, 491 and 495.

3. According to Alam, the Shah ordered him to pay $\$ 10,000$ per month to Zaher Shah in Italy and to buy the exiled King a house as well. The money was to come from the Iranian government's "secret budget." Alam is rather ambiguous about whether the exiled King received the financial support from Iran. Alam, Khofteghohay, pp. 569 and 537-538.

4. See Abdulreza H. Mahdavi, Siyasat-e Kharege-ye Iran Dar Douran-e Pahlavi [Iran's Foreign Policy During the Pahlavi Era] (Tehran: Alborz, 1979), pp. 471-473.

5. Harrison argued that the Shah's policies "triggered the chain of events culminating in the overthrow of the Mohammad Daud regime." See Selig S. Harrison, "The Shah, Not Kremlin, Touched off Afghan Coup," The Washington Post, May 13, 1979.
} 
The Soviet invasion of Afghanistan in December 1979 created a conundrum for Ayatollah Khomeini. ${ }^{6}$ He could neither remain reticent about the invasion of an Islamic country by "atheists," nor could he afford to antagonize the Soviet Union. The beginning of the Soviet occupation coincided with the US hostage crisis in Tehran that terminated decades of strategic cooperation between Iran and the United States and regrettably transformed the two former allies into bitter enemies. ${ }^{7}$ As Iran became increasingly isolated during the hostage crisis, it began to tilt in favor of the Soviet Union in order to neutralize the impending US threat. Thus, Iran staunchly condemned the occupation of Afghanistan and demanded the Soviet withdrawal, but it was exceptionally vigilant not to allow its policy toward Afghanistan to damage irrevocably its otherwise amiable relations with Moscow. ${ }^{8}$

Afghanistan, however, was not a top foreign policy priority for Iran, even though approximately 1 to 1.5 million refugees had fled to Iran. Winning the war with Iraq, a goal that was based more on revolutionary romanticism than reality, had become a dangerous fixation for Iran's clerical leadership that overshadowed all other issues. When Iran expelled Iraqi forces from its territory and penetrated into Iraq in 1982, Tehran squandered a propitious opportunity to end the war and instead made a strategic blunder by demanding Iraqi capitulation. Iran continued the war for another six long years, a useless and insane war that caused the death of thousands of people and the destruction of much of the infrastructures of both countries.

Iran played its "Afghan card" as an effective means to gain concessions from Moscow, to limit the Soviet supply of arms to Iraq during the eight-year Iran-Iraq War, to counter the looming US threat, and to tame the activities of the pro-Moscow Tudeh party as Khomeinists consolidated power in Iran. The essence of Iran's policy toward Afghanistan was to create an "ideological sphere of influence" by mobilizing and energizing the Afghan Shi'ites, which comprised about $20 \%$ of the population, while barely dealing with the Communist government of Afghanistan. Tehran's Shi ' $\mathrm{i}$ centered and parochial policy transformed the historically oppressed and marginalized Hazaras, Qizilbash, and Farsiwans Shi' ites into a disciplined and cohesive force. Tehran provided financial support to the Shi ites, gave them hope, trained a generation of activists, and established close links with the Afghan 'ulama.' The presence of Afghan refugees in Iran provided Tehran with a unique opportunity to train an indig-

6. See R.K. Ramazani, Revolutionary Iran: Challenge and Response in the Middle East (Baltimore: Johns Hopkins University Press, 1986); and Mohsen M. Milani, "Iran's Ambivalent World Role," in Comparative Foreign Policy, Steven W. Hook, ed. (New Jersey: Prentice Hall, 2002), pp. 219-244.

7. See Mohsen M. Milani, "The Hostage Crisis," Encyclopedia Iranica, Vol. VII (New York: Columbia University, 2004), pp. 525-535.

8. Khomeini allegedly agreed not to incite the Soviet Muslims against the Soviet Union in exchange for a pledge by Moscow to veto any UN sanctions against Iran. See Adam Tarock, "The Politics of the Pipeline," Third World Quarterly, Vol. 20, No. 4, August 1999, p. 805.

9. Hafizullah Emadi, "Exporting Iran's Revolution," Middle Eastern Studies, Vol. 31, No. 1, January 1995, pp. 1-12. Emadi claims that the Afghan Shi'ites received military training in Iran for up to six months and received a small monetary compensation as well. Some of them, he claims, were sent to fight Iraq. Emadi, "Exporting," p. 8. 
enous Afghan force that was to be relocated to Afghanistan at the opportune moment. ${ }^{10}$

Ironically, the Soviet occupying forces did not dominate the Hazarjat region in central Afghanistan, the stronghold of the Shi 'i community. ${ }^{11}$ It is not clear if this "hands-off" policy was adopted by Moscow because of the growing threat emanating from the Pakistani-based Islamic Resistance, or if it was a concession to Ayatollah Khomeini. Whatever the reason, this policy permitted Iran to create a sophisticated network inside Afghanistan, reinvigorating indigenous organizations, and creating new, disciplined forces, such as Hizbollah. Iran's investments paid off when the eight Iran-based Afghan-Shi'i groups formed an alliance in June of 1987.

The most revealing aspect of Iran's Afghan policy was not what Iran did, but what Iran did not do. Iran refused to become a "frontline" state and participate in the "Washington-Islamabad-Riyadh" axis that generously supported the Pakistani-based Resistance against the Soviet occupation. While Iran did not undermine the Resistance and publicly supported it as a legitimate movement against an illegitimate occupation, the leadership in Tehran made a precarious distinction between the Resistance's three main financiers and organizers. Iran enjoyed good relations with Pakistan under President Zia al-Haq, hoping to keep him distant from Washington. ${ }^{12}$ Ironically, Pakistan's Inter-Services Intelligence Directorate (ISI) was the main conduit for the distribution of US and Saudi financial aid to the Resistance. Even US weapons, including the deadly stinger missiles that paralyzed the Soviet military in Afghanistan, were distributed through the ISI. ${ }^{13}$

Iran considered the Saudi-US alliance to be a grave security threat and saw their fingerprints all over the Resistance. ${ }^{14}$ It is estimated that the US gave $\$ 3$ billion over the course of the 1980 s to the Resistance,,$^{15}$ while Saudi Arabia gave nearly $\$ 4$ billion, a sum that did not include the support given by individual Saudis or by charitable organizations. ${ }^{16}$ Saudi Arabia was also providing lavish financial support to lubricate Iraqi President Saddam Husayn's war machine against Iran. Iran was particularly alarmed about the invigoration of the madrasa system, which was spreading radical Wahabism among Pakistanis and Afghan refugees in Pakistan. While Khomeini considered Wahabism as “America's Islam," for Washington, Wahabism, with its uncom-

10. Cooley claims that some 15 training camps were established in Iran. John K. Cooley, Unholy Wars: Afghanistan, America and International Terrorism (London: Pluto Press, 2000), p. 103.

11. See Sayed Askar Mousavi, The Hazaras of Afghanistan: An Historical, Cultural, Economic and Political Study (New York: St. Martin Press, 1997).

12. Vali Nasr, "The Iranian Revolution and Changes in Islamism in Pakistan, India and Afghanistan," in N. R. Keddie and R. Matthee, eds., Iran and the Surrounding World (Seattle: University of Washington Press, 2002), pp. 327-352.

13. For a perceptive analysis of the impact of the role of US weapons on the Afghan crisis, see Alan J. Kuperman, "The Stinger Missile and U.S. Intervention in Afghanistan," Political Science Quarterly, Vol. 114, No. 2 (Summer 1999), pp. 219-263.

14. Oliver Roy, "Afghanistan: An Islamic War of Resistance," in Fundamentalism and the State, M. Marty and R.S. Appleby, eds. (Chicago: The University of Chicago Press, 1993), pp. 490-510.

15. Peter L. Bergen, Holy War, Inc. (New York: Free Press, 2001), p. 68.

16. Ahmad Rashid, Taliban (New Haven: Yale University Press, 2001), p. 197. 
promising anti-Shi ' $i$ proclivities, was perceived as a deterrent against Communism as well as an effective counter-force against Khomeinism. Thus, the US encouraged Muslim volunteers from the Islamic world to join the Resistance. The US was so obsessed with turning Afghanistan into the Soviet Union's own Vietnam, as well as undermining revolutionary Iran, that it conveniently ignored the ideological rigidity and extremism of the Resistance. ${ }^{17}$ One of the "unintended consequences" of that policy was that after the collapse of the Soviet Union, many of these militants, emboldened by the victory in Afghanistan, shifted their anti-Communism attitude towards an anti-American stance and became foot soldiers of the global Jihadi movement and al-Qa'ida. ${ }^{18}$

\section{CREATING A POLITICAL SPHERE OF INFLUENCE, 1988-1996}

Occupying Afghanistan proved infinitely more difficult and costly for the Soviet Union than invading it. Unable to stabilize Afghanistan, the Red Army was forced to leave, accelerating the auspicious collapse of the Soviet Union. In the international negotiations for the Soviet withdrawal, Washington and Moscow had both pledged not to interfere in Afghanistan, which they both considered to be devoid of any economic and strategic value. This doctrine of non-interference and benign neglect created a dangerous vacuum that transformed that country into a lethal battleground for a proxy war among Iran, Saudi Arabia, and Pakistan.

Saudi Arabia and Pakistan sought to undermine the incumbent Najibollah government and install a friendly, obedient government. Their ambitions, however, exceeded their capabilities. Saudi Arabia saw Afghanistan as an ideological springboard to expand Wahabism throughout Afghanistan and Central Asia, to neutralize Iran's revolutionary message, and to become the leader of the Islamic world. Pakistan's main goal was to install a Pushtun-dominated government, which would ideally accept the Durand line that demarcated the borders between Pakistan and Afghanistan when Pakistan was created and would allow Pakistan to expand its sphere of influence into Central Asia and possibly to become a lucrative bridge connecting Central Asia and the Arabian Sea. Such a government could have also provided Pakistan with a "strategic depth" which it would require in any war with India, its "perennial enemy."

Iran's objectives clashed with Pakistan's and Saudi Arabia's. After the end of the Iraq-Iran War, Iran became more assertive in Afghanistan; its foreign policy became somewhat pragmatic in the hope of lessening its international isolation and improving relations with its neighbors and with the West. ${ }^{19}$ What did not change were Iran's friendly relations with Russia and Iran's perception of the US as a national security threat. In that vein, 'Ali Akbar Hashemi-Rafsanjani, Speaker of the Majlis who had his eyes fixated on the presidency, announced in Moscow in the summer of 1987 that

17. A US Congressional Resolution (October 1984) referred to the members of the Resistance as "freedom fighters." See Kuperman, "The Stinger Missle," p. 227.

18. Bergen, Holy War, p. 90.

19. See Shireen Hunter, "Iran's Pragmatic Regional Policy," Journal of International Affairs, Vol. 56, No. 2 (Spring 2003), pp. 133-147. 
"we are prepared to assist you, so that after your departure there will be no US domination in Afghanistan." 20 Iran's other objectives were to insure stability on its borders with Afghanistan as it was rebuilding its own shattered economy, to support the establishment of a Tehran-friendly government in Kabul, to reduce the influence of Pakistan and especially Saudi Arabia in Afghanistan, and to transform itself into a critical trade and energy bridge between Central Asia, Afghanistan, and the Persian Gulf.

Iran consistently called for national reconciliation in Afghanistan and the formation of an inclusive, multi-ethnic government. At the same time, Iran substantially expanded its political sphere of influence by creatively exploiting language as a tool to unify the sizable Dari/Persian-speaking, non-Pushtun minorities. These Dari-speaking minorities thus became a formidable counterforce against the Pushtuns, who were supported by Pakistan and Saudi Arabia.

To solidify its new sphere of influence, Tehran formulated a two-pronged policy. On one hand, Iran encouraged the various Shi' $i$ groups to form the Hezb-e Wahdat (Party of Unity) in 1990, which became the largest Shi' $i$ organization. On the other hand, Iran, in 1991, signed an important agreement with Tajikistan and Afghanistan's Jamiat-e Islami (Islamic Society), a large organization under the leadership of Burhanuddin Rabbani and Ahmad Shah Mas'ud. A major step toward unity was taken when the Tajik commander, Ahmad Shah Mas'ud, along with Abdul Rashid Dostam, an Uzbek military leader, formed a loose alliance with the Hezb-e Wahdat and several smaller Shi 'i groups. Two days before a team of UN-selected Afghans was to establish a new post-Soviet government, the alliance under the leadership of Mas 'ud staged a preemptive strike and toppled Najibullah's government in April of 1992. Two months later, Rabbani became President of this new government. While Iran's role in the putsch by Mas'ud remains ambiguous, his victory would probably not have been possible without Iran's role in unifying the non-Pushtuns.

Iran unhesitatingly recognized the new government, which was controlled by the non-Pushtun Dari-speakers. Much to Iran's exasperation, however, the new government neither governed Afghanistan effectively nor saved it from a ferocious civil war. The casus belli of the civil war was ethnic rivalry, reinforced by warlordism. The control of the government by the non-Pushtuns, for example, generated venomous resentment among the Pushtuns, who had historically dominated Afghan politics. Moreover, the polycephalic movement against the Soviet occupation had empowered many ambitious warlords. These warlords exploited ethnic rivalry to advance their own agendas, and formed alliances of convenience with the same rapidity and opportunism that they as soon betrayed. ${ }^{21}$ They had created their own little fiefdoms and were determined to defy any centralization of authority.

During the civil war, competition intensified between Pakistan and Saudi Arabia

20. Quoted in Emadi, Exporting, p. 10.

21. For details, see Ali A. Jalali "Afghanistan: The Anatomy of an Ongoing Conflict," Parameters (US Army War College Quarterly), Vol. 31, Issue I (Spring 2001), pp. 85-98. 
on the one side, and Iran on the opposite side. ${ }^{22}$ Both Pakistan and Saudi Arabia, who felt embarrassingly outmaneuvered by Mas'ud's preemptive strike, viewed the new Afghan government as being suspiciously and dangerously aligned with Iran. The first warlord they sought for destabilization of the government was Gulbuddin Hekmatyar, the single largest recipient of Saudi and US aid in the 1980s. A selfproclaimed defender of the Pushtuns, Hekmatyar created utter chaos and formed fleeting alliances with anyone willing to undermine the government.

Iran sought to strengthen the Afghan government as well as the Shi'ites and to find a peaceful resolution to a violent civil war. This Herculean task required the kind of resources and diplomatic skills that Iran lacked. Additionally, Iranian policy failed because of erratic changes in the policies of the Afghan government and Iran's own inconsistent maneuvers. Pushed in different directions by constituencies that had irreconcilable agendas, the Afghan government alienated too many forces and failed to form any enduring alliances with the major players in the civil war. Its different approaches toward Iran are a case in point: Rabbani followed a more cautious and conciliatory approach toward Iran, and played the foreign powers against one another in the hopes of receiving concessions from all of them. Mas'ud, however, played hardball with Iran. Mas'ud, who was receiving financial support from Pakistan and Saudi Arabia, slowly distanced himself from Tehran and bitterly complained about Iranian intervention in his country. This inconsistent policy by Kabul angered Tehran, which responded by increasing its support to the Shi 'ites as well as to various warlords, including General Dostum, Isma'il Khan, and even Hekmatyar. This erratic policy by Iran proved to add high-octane fuel to the civil war.

The Afghan government also was reluctant to share power with the Shi 'ites or Pushtuns, as Iran had persistently demanded. In fact, the government sought to disarm the Wahdat Party outright. Abdul Rasool Sayyaf, leader of the Pushtun-dominated Itteha-e Islami and one of the closest allies of Saudi Arabia, played a destructive role in the 1992-93 confrontations between Mas 'ud and the Wahdat Party. ${ }^{23}$ In those deadly confrontations, hundreds of Shi'ites were killed. In retaliation, the Wahdat party formed a fleeting alliance with Hekmatyar and Dostum in January of 1994, unleashing one of the deadliest rocket and artillery attacks on Kabul, reportedly killing some 25,000 people. ${ }^{24}$

In short, life in Afghanistan during the civil war, to paraphrase Thomas Hobbes, was nasty, brutish, and short with the war of all against all. It was from this prevalent climate of hopelessness and despair that the Taliban rose to power.

22. Rasul Bakhsh Rais, "Afghanistan and the Regional Powers," Asian Survey, Vol. 33, No. 9 (September 1993), pp. 905-922.

23. He studied in Saudi Arabia and received "hundreds of millions of dollars in Saudi aid," Bergen, Holy War, p. 54.

24. Fundamentalism Reborn, William Maley, ed. (New York: New York University Press, 2001), p. 35. 


\section{HELPING CREATE A SPHERE OF RESISTANCE AGAINST THE TALIBAN}

The Taliban arose as an obscure group of young Pushtun religious students. It began "as a kind of experimental Frankenstein monster" and was "created in the laboratories, so to speak, of Pakistani intelligence, the ISI - in order to produce a counter-force to Iran and Iranian Islamism." ${ }^{25}$ Ironically, Iran was astonishingly slow both to decelerate the phenomenally fast rise of the Taliban movement and to recognize its intrinsically belligerent outlook towards Iran and Shi 'ism.

By mid-1994, under Prime Minister Benazir Bhutto, Pakistan changed the direction of its Afghan policy. Pakistan, much sooner than Iran, had concluded that the Afghan government was too hopelessly incompetent and divided to end the civil war. Having also lost confidence in Hekmatyar, the ISI shifted covert logistical support to the Taliban. The Saudi General Intelligence Agency, under Prince Turki al-Faisal, joined Pakistan in this endeavor and provided generous financial and material support to the Taliban in their attack on Kabul. ${ }^{26}$ Neither the Afghan government nor Iran appear to have been fully aware of the substantial aid being covertly given to the Taliban. Similarly, they did not connect the relevant dots to discover that a grand design was being hatched to establish a Pushtun-Saudi style theocracy in Afghanistan. (In 1994, two years before the Taliban overthrew the government in Kabul, an explosion in the Shrine of Imam Reza in Mashhad killed 26 pilgrims and injured dozens, mostly women. There is some evidence that the bombing was related to al-Qa 'ida. ${ }^{27}$ ) The Afghan government, supported by Iran, resorted to negotiations and even attempted to drive a wedge among the Pushtuns by appointing the notorious Hekmatyar as Prime Minister of a "national unity" government. These maneuvers all proved futile.

The Taliban's dazzlingly rapid ascent to power disoriented Iran and forced it into a defensive and reactive posture. Iran suffered its first setback when 'Abd al-'Ali Mazari, a prominent leader of the Hezb-e Wahdat who was under fire by the forces of Ahmad Shah Mas'ud, struck a deal with the Taliban in 1995. He did not enjoy a happy fate, however, as he was taken into custody by the Taliban and later died mysteriously in a helicopter crash. Although Iran's role in Mazari's bizarre deal with the Taliban remains vague, his defection weakened the Shi 'ites and further emboldened the Taliban. In the same year, Herat fell under Taliban control. This was a decisive moment when Iran could have changed its course, but instead it continued with its failed policies and offered token support to Isma'il Khan, Herat's strong man and Iran's ally, who staged an ineffective counter offensive and was subsequently arrested by the Taliban. The Taliban ultimately overthrew Rabbani in 1996. This was a serious

25. Cooley, Unholy Wars, p. 146.

26. Rashid, Taliban, p. 201.

27. According to MSNBC, Ramzai Yousef, one of the planners of the first attack on the World Trade Center in New York, and the "People's Mujahedin" (Mujahedin-e Khalq) were behind the massive explosion. See http://www.msnbc.msn.com/id/4677978/, (p. 4). 
defeat for Iran, and a fleeting victory for both Pakistan and Saudi Arabia.

During the Taliban's dominance, Iran's policy was based on four pillars. Firstly, it refused to recognize the Taliban government and sought to return Rabbani to power. Secondly, it supported the Northern Alliance as a counterforce against the Taliban. Thirdly, it sought to avoid any direct military engagement with the Taliban. Finally, it aimed to intensify its activities in the United Nations" "Six Plus Two" negotiations concerning the future of Afghanistan. ${ }^{28}$

Not since the independence of Afghanistan, in 1919, had there been an Afghan government as antagonistic toward Iran as the Taliban; not since Saddam Husayn invaded Iran in September 1980 had any Iranian neighbor posed as great a security threat than the Taliban. Iran feared that Taliban rule would increase instability on its eastern borders and accelerate the flood of refugees into Iran. Tehran labeled the Taliban "narco-terrorists," who provided sanctuary to terrorist organizations and who "cherry picked" elements of both Islam and Pushtun tribal traditions to justify an unIslamic and repressive ideology.

The "Kabul-Islamabad-Riyadh" axis generated serious tension in Iran's relations with Pakistan and Saudi Arabia, and once again turned Afghanistan into a battleground for a proxy war among them. Although the three regional players were diligently cautious to not allow the crisis to irretrievably damage their otherwise friendly relations, their differing agendas collided. While Pakistan provided generous logistical, military and political support to the Taliban, Saudi Arabia magnanimously gave petrodollars to them, hoping to spread Wahabism and strengthen its role as a leader of the Islamic world. Saudi Arabia directly funded the notorious security service, the Ministry of Enforcement of Virtue and Suppression of Vice, whose antediluvian ideology and draconian measures transformed Afghanistan into a repressive countrysized prison. ${ }^{29}$

Both Saudi Arabia and Pakistan also shared a common economic objective: the construction of a 1,040-mile long Turkmenistan-Afghanistan-Pakistan pipeline. ${ }^{30}$ The American UNOCAL and Delta Oil of Saudi Arabia were to be the main financiers of the project, which enjoyed some support within the Clinton Administration. Construction of this $\$ 2.5$ billion project was a major strategic challenge to Iran, which insisted that a pipeline through Iran would be much cheaper, shorter, and safer.

Saudi Arabia and Pakistan used their considerable clout in Washington to portray the Taliban as a force that could restore order, neutralize Iran, and provide a safe gateway for US interests within Central Asia. The Taliban played their own "Iran card" rather skillfully, portraying themselves to be a bastion against "Iranian extrem-

28. They included Iran, Pakistan, China, Tajikistan, Uzbekistan, Turkmenistan, Russia, and the US.

29. Human Rights Watch, Afghanistan: Crisis of Impunity. The Role of Pakistan, Russia and Iran in Fuelling the Civil War, Vol. 13, No. 3, July 2001 (c), p. 31. According to the same report, the Ministry of Enforcement of Virtue and Suppression of Vice was the most powerful "government organ" in Afghanistan, p. 32.

30. Testimony by John J. Maresca, Vice President, International Relations, UNOCAL Corporation to House Committee on International Relations [Subcommittee on Asia and the Pacific], February 12, 1998, p. 5. 
ism." They closed the Iranian Embassy in Kabul in 1997, accused Iran of blatant interference in Afghanistan, and pushed the two countries to the precipice of war. There were those in Washington who did not initially view the Taliban as a major threat to the United States and welcomed the Taliban as a counterforce against Iran. ${ }^{31}$ Assistant Secretary of State for South Asian Affairs, Robin L. Raphel, pointed out that the Taliban had to be "acknowledged" as an "indigenous movement" with "staying power." ${ }^{32}$ Still, the Clinton Administration, much to its credit, refused officially to recognize the Taliban government, and Secretary of State Madeline Albright remained outspokenly critical of the Taliban's blatant violations of human rights. Only Saudi Arabia, Pakistan, and the United Arab Emirates recognized the Taliban government.

Iran refused to recognize the Taliban, assisted the Northern Alliance, and helped create a sphere of resistance within Afghanistan. In fact, Iran posed "the strongest opposition to their [Taliban's] ascendancy." ${ }^{33}$ In seeking to oust the Taliban, Iran, however, miscalculated Pakistan's intentions. Publicly, both countries insisted that the Afghan crisis had no military solution. In the words of Prime Mininster Nawaz Sharif, who visited Tehran in June of 1997, all factions in Afghanistan "should sit behind a negotiating table and try to resolve their differences in a peaceful manner." ${ }^{34}$ In practice, however, neither Pakistan nor the Taliban had any such plan. This critical fact became abundantly clear to Iran when the Taliban attempted to capture Mazar-eSharif, the interim capital of the Northern Alliance.

In that crucial battle, Iran provided key support to the Northern Alliance, which inflicted heavy causalities on the Taliban. With considerable logistical support from Pakistan, the Taliban ultimately prevailed in that melee. The Taliban then proceeded to commit genocide, massacring male members of the Hazara, Tajik, and Uzbek communities - killing at least 2,000 people. They also took many prisoners who were "transported in large container trucks capable of holding up to 150 people ... In two known instances ... nearly all of the men inside had asphyxiated or died of heat stroke inside the closed metal containers." ${ }^{35}$

Infuriated by the Iranian support, the Taliban kidnapped eight Iranian diplomats and one journalist. Iran relied on diplomacy in an attempt to free the hostages, while simultaneously threatening military force by massing more than 70,000 troops on its

31. In 1996, Zalmay Khalilzad (later Ambassador to post-Taliban Afghanistan) wrote that although the Taliban posed a threat, there are some "common interests between the United States and the Taliban." See "Afghanistan: Time to Reengage," The Washington Post, October 7, 1996. In 2000, he accused the Clinton Administration of "underestimating the threat posed to regional stability and to U.S. interests" by the Taliban. See Z. Khalilzad and D. Byman, "Afghanistan: The Consolidation of a Rogue State," The Washington Quarterly (Winter 2000), p. 66.

32. Richard MacKenize, "The United States and the Taliban," Fundamentalism Reborn, William Maley, ed. (New York: New York University Press, 2001), pp. 35 and 91.

33. Shahid M. Amin, Pakistan's Foreign Policy: A Reappraisal (Oxford: Oxford University Press, 2000), p. 114.

34. Hamshahri, June 18, 1997; 28 Khordad 1376.

35. Human Rights Watch: The Massacre in Mazari Sharif, Vol. 10, No. 7, (c) November 1998, p. 2. 
eastern border. Hojatolislam Rafsanjani condemned hostage taking as a violation of the "established norms of diplomacy," as if the Tehran hostage crisis of 1979 was seemingly a fiction. Hojatolislam Hasan Rouhani, an influential member of Iran's foreign policy establishment, declared that Iran was suspicious of Pakistan's intentions and that Pakistan was ultimately "responsible for the safety of Iranian hostages." ${ }^{36}$ Neither the threat of retaliation nor the endeavors of diplomacy proved effective, however. In September of 1998, the Taliban "found" the corpses of the hostages, but accepted no culpability.

Iran promised to punish the "savage" Taliban, and began massing some 200,000 troops on its eastern border. The Iranian Foreign Ministry blamed Pakistan outright for the death of the hostages, while Ayatollah Khameini blamed "American oil and gas companies," as well as elements of the Pakistani army, for the "Taliban conspiracy." ${ }^{37}$ Iran's top leadership, including President Muhammad Khatami and Ayatollahs Khameini and Hashemi Rafsanjani opposed entanglement in another war, however, and thus opposed military retaliation against the Taliban. Rafsanjani reportedly said that "Afghanistan is like a swamp; anyone can fall into it, but a few can get out of it safely and undamaged" 38

Iran's harsh rhetoric and ultimately empty threats spurred the Taliban on to increasing belligerence. They ransacked the Iranian cultural center in Mazar-e Sharif, setting the library ablaze, and violently crushed an uprising in Herat in May of 1999, which they claimed was instigated by Iran. ${ }^{39}$ They intensified their ruthless persecution of Shi 'ites, particularly the Hazara, labeling them as infidels. ${ }^{40}$ They decreased the amount of life-giving water flowing from the Helmand River to Iran, forcing Iran to take the issue before the United Nations.

Throughout the rule by the Taliban, Iran, India, and Russia provided support for the Northern Alliance, while the majority of the rest of the world remained coldly silent regarding the Taliban's egregious violations of Afghans' basic human rights. Iran dispatched military instructors to the Northern Alliance, with the Wahdat Party and Ahmad Shah Mas 'ud receiving the lion's share. An estimated 80 to 150 men were being trained by Iranian military instructors at any given time. ${ }^{41}$ Until late 2002, Iran was the "principal source of military assistance to the United Front, providing signifi-

36. Hamshahri, August 17, 1998, 26 Mordad 1377.

37. Hamshahri, September 15, 1998, 24 Shahrivar 1377.

38. The author's interview with an Iranian university professor, Tehran, March 2001.

39. Gholamreza Amirkhani, “Afghanistan's Lost Splendor," American Libraries, December 2001, p. 19. Director of Iran's National Library, AmirKahni claims that the Taliban destroyed another library with 55,000 volumes at Pol-e Khomri. See also, Vahid Mojdeh, Afghanistan Va Panj Sal-e Solte-ye Taliban [Afghanistan: Five Years of Dominance by the Taliban] (Tehran, Nashrani, 2002); and Abdullah Rafiee, Kabul Ta Baghdad [From Kabul to Baghdad] (Tehran: The Press of Iran's Armed Forces, 2003). Rafiee offers a military and strategic analysis of the recent events in Iran and Afghanistan.

40. For details, see www.hazara.net/taliban/fitwa/fitwa.html. The site provides information on the recently-discovered mass graves of the victims of the Taliban.

41. Human Rights Watch: Crisis of Impunity; The role of Pakistan, Russia and Iran in Funding the Civil War, Vol. 13, No. 3, July 2001, pp. 39-40. 


\section{$246 \star$ MIDDLE EAST JOURNAL}

cant levels of the weapons and training." 42 There is much truth to the assertion by a senior Afghan government source that "without Iran, most Northern Alliance commanders couldn't have operated in Afghanistan at a time when they had no other source of international support." 43

It is said that one difference between moderates and extremists is that the latter do not know when to stop. What sealed the fate of the Taliban was not only the Northern Alliance, but the Taliban's symbiotic relationship with the al-Qa'ida, which sponsored the barbaric attacks on the United States on September 11, 2001. By refusing to extradite Bin Ladin to the US, the Taliban wrote its own obituary.

\section{THE FALL OF THE TALIBAN AND US-IRAN COMPETITION IN AFGHANISTAN}

The forcible removal of the Taliban by the United States was an unintentional gift to Iran that created a strategic configuration with both enticing opportunities as well as dangers for Iran. One benefit for Iran was that the fall of the Taliban, Iran's nemesis, forced Pakistan and Saudi Arabia, Iran's main competitors in Afghanistan, into a defensive posture. They had gambled high stakes by betting on the monster they created, and they lost it all. Pakistan made a deathbed conversion, joining the "War on Terrorism," and was rewarded by the US with lucrative financial assistance and the removal of economic sanctions which had been imposed in response to Pakistan's nuclear tests. Although 15 out of the 19 known executors of the September $11^{\text {th }}$ terrorist attacks came from the Kingdom, Saudi Arabia was gracefully allowed by Washington to disappear gently from the political radar of Afghanistan. Today, Saudi Arabia is quietly engaged in the reconstruction of Afghanistan.

Tehran was delighted to see its friends in the Northern Alliance regain considerable power in Kabul. Although Iran viewed the presence of thousands of American troops in Afghanistan with trepidation, and did not welcome the United States as its new neighbor, it was cautiously optimistic that the common goal of fighting a perfidious enemy in the Taliban would accelerate the rapprochement with the US that had begun during the last years of the Clinton Administration. This optimism was further strengthened by the fact that President George W. Bush was viewed in Tehran as being closely linked to the oil industry; Vice-President Dick Cheney was also fondly remembered for calling for a partial lifting of unilateral US sanctions on Iran when he led Halliburton. Moreover, there were secret, back-channel talks in Geneva regarding Afghanistan between the United States and Iran, even before the September $11^{\text {th }}$ attacks. ${ }^{44}$

42. Human Rights Watch: Crisis of Impunity, p. 35.

43. Thomas H. Johnson, "Ismail Khan, Heart and Iranian Influence," Strategic Insights, Vol. III, Issue 7, July 2004, p. 3.

44. For details, see Mohsen Aminzadeh, Diplomasee-ye Iran az dourey-e Khatami to Ahmadinejad [Iranian Diplomacy from Khatami to Ahmadinjead]. Sharagonline.ir/spe/spe/archives/ 2005_327_19_23_28_Print.php. Sharag newspaper, a reform-oriented newspaper, conducted an indepth interview with Mr. Aminzadeh, a top official of the Iranian Foreign Ministry under Khatami. 
There were additional, more compelling reasons for this optimistic attitude within Iran. On one hand, the United States' popularity was at its peak. The remarkable popular sympathy with the innocent victims of the September $11^{\text {th }}$ terror attacks, as evidenced by spontaneous vigils and denunciations of Bin Ladin in the mass media, was more visible in Iran than in other Islamic countries. On the other hand, President Khatami, one of the first world leaders to condemn the September $11^{\text {th }}$ terrorist attacks as being anti-Islamic and barbaric, had heavily invested in his "dialogue among civilizations," and thus favored improved relations with the US. Under these auspicious conditions, Iran came to play an important role in the campaign to overthrow the Taliban.

Two days before the terrorist attacks on the United States, Ahmad Shah Mas 'ud, the leader of the Northern Alliance, was assassinated, most likely by al-Qa 'ida. Anticipating a military retaliation by the United States on Afghanistan in response to the impending terrorist attacks, the assassins undoubtedly hoped to decapitate and disorient the Northern Alliance and create a vacuum in leadership, thus complicating any American military intervention. Only a day after the assassination, however, the leadership vacuum was filled; with Iran's help, a leadership council consisting of "Marshal Fahim, Dr. Abdullah, and Ghanounni" was formed. ${ }^{45}$ Soon thereafter the United States began to work closely with the Northern Alliance, and Iranian advisors rubbed shoulders with American military personnel in the Northern Alliance controlled areas. Additionally, Tehran announced that it would provide sanctuary to distressed American military personnel inside Iranian territory, and allowed the US to transport food and humanitarian goods to Afghanistan through Iran's territory. A top official of the Iranian Foreign Ministry under Khatami claims that it became rather clear in Iran's back-channel talks with the US that Washington "did not have a clear plan for the post-Taliban Afghanistan," and that Iran offered advice and warned the US about major fault lines in Afghanistan. ${ }^{46} \mathrm{He}$ also claims that "Americans paid attention to our [Iran's] sensitivities." It is reported that Iran even "brought out maps to try to tell the United States the best targets to bomb" in Afghanistan. ${ }^{47}$

Iran's participation in the UN-brokered, US-sponsored Bonn Conference in December of 2001 was equally significant. ${ }^{48}$ The major Afghan factions participated in the conference and signed the Bonn Agreement, laying the groundwork for the future of the Afghan government. Iran and the US favored a new government free of the Taliban, and agreed on many other critical issues. Dr. Muhammad Javad Zarif, Iran's observer at the conference, was asked by the US to intervene when talks stalled: "We [Iranians] allowed General Fahim [of the Northern Alliance] to bring only one

45. See Diplomasee-ye Iran, p. 5.

46. See Diplomasee-ye Iran, p. 5.

47. See James Risen, State of War: The Secret History of the CIA and the Bush Administration (New York: Free Press, 2006) p. 215. Risen's claim has not been corroborated by Iran, nor does he identify his source.

48. For the Bonn Agreement, see Report for Congress: Afghanistan: Challenges and Options for Reconstructing a Stable and Moderate State (Washington, DC: Congressional Research Service, 2002), Appendix 1. 
division inside Kabul, and proved all of Pakistan's fear of a bloodbath to be baseless." ${ }^{49}$ Although it originally favored an interim government headed by Rabbani, Iran dropped its proposal in support of Hamid Karzai, who was the US choice. Iran also pressured a reluctant Isma'il Khan, the self-appointed Emir of Herat, to support Karzai.

During the first year of the new Afghan government, the rapprochement between the United States and Iran continued as they competed for influence in Afghanistan. On January 3rd, 2002, however, Israeli Defense Forces captured what they claimed to be a Palestinian Authority-owned freighter, the Karine A, loaded with 50 tons of weapons. The IDF Chief of General Staff, Shaul Mofaz, who is an Iranian by birth, confirmed that some of the confiscated weapons were Iranian made..$^{50}$ It was also reported that the freighter had been loaded with weapons in Iran. Although Iran dismissed the allegation as an "Israeli conspiracy" to derail US-Iran negotiations over Afghanistan, the incident nevertheless became a catalyst for the rapid deterioration of US-Iran relations. A few weeks after the incident, President Bush included Iran as a member of the "Axis of Evil" in his January 2002 State of the Union speech.

After the presidential speech, the rhetoric from Washington and Tehran returned to a hostile and threatening tone. Hashemi Rafsanjani claimed that the US intended "to make a nest for themselves here [Central Asia]." The Pasdaran commander warned that the next target after Afghanistan would be Iraq, and then other countries. Hassan Rouhani claimed that "the Bush Doctrine" was designed to destabilize Iran." ${ }^{11}$ Iran defiantly released Hekmatyar, who quickly joined the anti-Karzai forces. ${ }^{52}$ In Washington, George Tenet, Director of the Central Intelligence Agency, declared that Iran's initial signs of cooperation had "eclipsed" and that "while Iran's officials express a shared interest in a stable government in Afghanistan, its security forces appear bent on countering the US presence. This seeming contradiction in behavior reflects deepseated suspicions among Tehran's clerics that the US is committed to encircling and overthrowing them." ${ }^{3}$ Zalmay Khalilzad, President Bush's envoy to Afghanistan and now US envoy to Iraq, condemned Iran's un-elected officials - a clear reference to conservative clerics - for destabilizing Afghanistan, suggesting that they "feel threatened by the emergence of a moderate and Western-oriented Afghanistan that might encourage the Iranian people to demand the same for their own country." ${ }^{54} \mathrm{He}$ accused Iran of harboring members of al-Qa 'ida, and of sending subversive elements to foment mischief in Afghanistan, a claim both Iran and the Karzai government denied.

49. Kaveh Afrasiabi and Abbas Maleki, "Iran's Foreign Policy After 11 September," The Brown Journal of World Affairs, Volume IX, Issue 2 (Winter/Spring 2003), p. 259; see also Zarif's interview with Time, January 25, 2002.

50. www.jewishvirtuallibrary.org/jsource/peace/paship.html.

51. Hamshahri, July 20, 2002, 29 Tir, 1381.

52. Risen, State of War, p. 215.

53. George J. Tenet, "Worldwide Threat," Testimony before the Senate Armed Services Committee, March 19, 2002, p. 6. See: http://www.cia.gov/cia/public_affairs/speeches/2002/senate_select_hearing_ 03192002.html.

54. Zalmay Khalilzad, "Speech to the American-Iranian Council,” March 13, 2002. 
Despite the harsh rhetoric between Washington and Tehran, Iran's Afghan policy did not change after the "Axis of Evil" speech. This lack of shift in policy lent credence to a suggestion by a Western diplomat that "Iran's game is to be publicly obstructive and privately constructive." 55

\section{IRAN AND KARZAI IN THE KHATAMI ERA}

With Hamid Karzai as the head of the Interim Authority, and with the Northern Alliance as a major power broker in the new government, Iran reformulated its Afghan policy to achieve four main goals: to collaborate with the Karzai government without abandoning its support for Iran's other allies in Afghanistan; to engage heavily in the reconstruction of Afghanistan in order to create an "economic sphere of influence" and transform Herat into a buffer zone; to avoid direct confrontation with the US while pressuring Kabul gradually to reduce US influence; and to reduce the flow of narcotics to Iran.

The bilateral relations were generally friendly. Karzai appealed to both the United States and Iran not to allow their differences to poison their policies toward Afghanistan. While he cannot survive without generous US support, Karzai recognizes Iran's potential to foment instability by unifying his opponents. Karzai has repeatedly paid tribute to the "unforgettable support" of Iran, which has "behaved like the brother of the Afghan people." In his official visit to Afghanistan in 2002, President Muhammad Khatami declared that "today, the Afghan nation has a government that is based on its own will ... the stability and security of Afghanistan is the same as our own security and stability." ${ }^{56}$ Moreover, the two countries signed a number of bilateral agreements dealing with issues ranging from fighting terrorism to economic cooperation. ${ }^{57}$

The bilateral relations, however, were not devoid of tension. The status of Afghan refugees, estimated to be over 2 million with only 900,000 of them properly identified, was a continuing source of friction between the two neighbors. ${ }^{58}$ Some refugees returned to their homeland since the fall of the Taliban, but a significant number returned to Iran. ${ }^{59}$ The presence of the multinational troops in Afghanistan was also a sensitive issue. While Karzai favors their presence to consolidate his own rule and to stabilize the country, Iran demands their withdrawal. Finally, the "pipeline politics" continued to taint relations between the two countries: Iran's vehement opposition to the Turkmenistan-Afghanistan-Pakistan pipeline, and its own proposed $\$ 7$ billion, 2,600 kilometer Iran-Pakistan pipeline, angered many Afghans, who accuse

55. Romesh Ratnesar, "Tehran's Game,” Time, February 4, 2002, p. 42.

56. "Karzai, Khatami Press Conference," BBC Monitoring, South Asia, Radio Afghanistan (Kabul), August 13, 2002.

57. Hamshahri, February 27, 2002, 8 Esfend 1383.

58. BBC Persian, February 19, 2006. www.bbc.co.uk/persian/iran/story/2006/02/printable/ 060219_mv-afghans-iran.shtml.

59. Foreign Minister Mattaki is quoted as saying that the Iranian Embassy in Afghanistan is issuing up to 2,000 visas per day. "Afghanistan, Iran Sign Consular Cooperation Agreement," BBC Worldwide Monitoring, South Asia, December 26, 2005. 
Iran of undermining their country's economic well-being.

From the Iranian perspective, the most contentious issues, however, were opium production in Afghanistan, Karzai's recent campaign to undermine the power of warlords friendly to Iran, and his policy of increasing the Puhstun presence in his government. Afghanistan is producing more opium today than it ever produced under the Taliban, and has become "a narco-state." 60 In 2005, total export value of opium to neighboring countries was a staggering $\$ 2.7$ billion, or about $52 \%$ of Afghanistan's $\$ 5.2$ billion GDP. ${ }^{61}$ Although opium production in 2005 was slightly lower than 2004 , it is still dangerously high. Iran has been cautious not to blame Karzai directly, even if hundreds of its security forces have recently been killed in clashes with traffickers. As usual, the United States is labeled as the easy scapegoat: "Are these people [Americans] who with the aid of their satellites monitor the car numbers of the Afghans in the deserts to track down terrorists unable to detect poppy farms?"62 asked Rafsanjani. Opium production and distribution generates substantial revenues for terrorist groups and subversive elements which could further destabilize the 560 miles of common borders between Iran and Afghanistan.

Karzai's policies to centralize Kabul's authority and to increase the Pushtun presence in the government generated new stress in the bilateral relations. These policies are incompatible with Iran's position that a truly multi-ethnic, federal Afghan system, with both a strong center and equally strong provinces, is the most effective system for insuring stability in Afghanistan. There are now disturbing signs that "inter-ethnic tension" has been exacerbated. ${ }^{63}$ In Karzai's cabinet in 2003, for example, Tajiks, Uzbeks, and Shi 'ites were well represented, while the Northern Alliance controlled the defense and foreign ministries ${ }^{64}$ After the presidential election in 2004, Karzai, a Durrani Pushtun, has increased the representation of the Pushtuns under the pretext of bringing technocracy to his cabinet. ${ }^{65}$

Complementary to this policy of Pushtunization is the campaign to "demobilize, disarm and reintegrate" (DDR) the centrifugal forces. Toward this goal, Karzai stripped Isma'il Khan of his governorship of Herat. General Muhammad Fahim was also removed as one of Afghanistan's vice-presidents. Despite these changes, Karzai's authority has not extended far beyond Kabul. The power bases of Isma'il Khan and Fahim have not been eroded, and they remain influential figures. It is estimated that

60. Thomas H. Johnson, "The Prospects for Post-Conflict Afghanistan: A Call of the Sirens to the Country's Troubled Past,' Strategic Insights, Volume V, Issue 2 (February 2006), p. 2.

61. United Nations Office on Drugs and Crime, Summary Findings of Opium Trends in Afghanistan, 2005, September 12, 2005, p.1. See: www.unodc.org/pdf/afg/2005SummaryFindingsOfOpium TrendsAfghanistan.pdf.

62. "Rafsanjani Condemns Israeli Attacks Against Palestinian Refugee Camps," BBC Monitoring, South Asia from Voice of Islamic Republic of Iran, March 8, 2002.

63. Johnson, The Prospects, p. 17.

64. See the Hizb-e Wahdat, http://geocities.com/wahdat_magazine/governmental.html. See also Johnson, The Prospects, p. 5.

65. Johnson, The Prospects, pp. 5, 8 and 17; Gulshan Dietl, "War, Peace and the Warlords: The Case of Ismail Khan of Herat in Afghanistan," Alternatives: Turkish Journal of International Relations, Vol. 3, Nos. 2 \&3 (Fall 2004), pp. 41-66. 
Fahim has a 50,000-strong militia under his personal command. ${ }^{66}$

Karzai's recent maneuvers have surely increased the bilateral tension. Although Karzai has indicated on many occasions that "Iran has never interfered in internal affairs of Afghanistan," there is some evidence to the contrary. ${ }^{67}$ During the presidential election in 2004, while Iran was publicly supporting the elections, it used the Mashhad radio, broadcast in Persian, to question the legitimacy of the election, calling Karzai the "stooge of the US." ${ }^{68}$ Anis, an Afghan newspaper, has accused Iran of fomenting anti-US sentiment, citing the protest over alleged desecration of the Koran as an example, a charge Iran vehemently denies. ${ }^{69}$

\section{IRAN AND AFGHAN RECONSTRUCTION}

One of the main objectives of Iran is to create an "economic sphere of influence" in Afghanistan, with the ultimate goal of becoming the hub for the transit of goods and services between the Persian Gulf, Afghanistan, Central Asia, China, and India. Clearly, the economic sphere of influence would also enhance Iran's political and security objectives. At the International Pledging Conference in Tokyo, in January of 2002, Iran committed $\$ 560$ million towards Afghan reconstruction, making Iran the leading contributor; Iran pledged approximately $12 \%$ of the total $\$ 4.5$ billion reconstruction assistance. During the London Conference on Afghanistan Reconstruction in 2006, Iran pledged an additional $\$ 100$ million, and announced that the last installment of its original $\$ 560$ million commitment would be delivered before the end of 2006. ${ }^{70}$

The bulk of these Iranian investments lie in the Herat region, and involve infrastructural projects, road and bridge construction, education, agriculture, power generation, and telecommunications projects. Iran has helped rebuild Afghanistan's radio and television infrastructure, and has increased its own radio and television programs in Dari. From 2002-2003, a total of $\$ 1.5$ billion of exports flowed to Afghanistan; Iran's share was only $\$ 120$ million. ${ }^{71}$ The amount of trade has increased significantly since 2002 , thanks to improved roadways, lower tariffs, and new customs checkpoints. In 2005 , the annual value of the trade was increased to $\$ 250$ mil-

66. Dietl, "War, Peace and the Warlords," p. 58.

67. Hamshahri, February 27, 2002, 8 Esfend 1383.

68. See Bill Samii, "Tehran Talks Out of Both Sides of Mouth on Afghan Election," RFE/RL Newsline, Vol. 8, No. 197, October 18, 2004. Many others questioned the legitimacy and fairness of the elections. See, for example, M. Nazif Shahrani, “Afghanistan's Presidential Elections: Spreading Democracy or a Sham?' Middle East Report Online, October 8, 2004. For the problems of building democracy in Afghanistan, see Barnett R. Rubin, "(Re)Building Afghanistan: The Folly of Stateless Democracy," Current History, 103 (April 2004), pp. 165-170

69. "We Should Not Fall Victim to Behind-the-Scenes Politicking," BBC Monitoring, South Asia, Anis, May 19, 2005.

70. BBC Persian, January 31, 2006. See: www.bbc.co.uk/persian/afghanistan/story/2006/01/printable/060131_he_afghanaids_html.

71. "Iran Exports \$10m to Afghanistan," BBC, Monitoring International Reports from IRNA, October 1, 2002. 
lion. $^{72}$

Iran also allocated some $\$ 43$ million to improve a 125 -kilometer "Golden Transit Route," linking the Dougharoun region in Iran to Herat. ${ }^{73}$ The highway was inaugurated when Karzai visited Iran in 2005. Iran has also announced its biggest project in the coming years: the construction of a 176-kilometer railroad from Iran to the city of Herat. ${ }^{74}$ Iran has also provided loans and grants to Tajikistan for the construction of a 5 kilometer Anzab tunnel. Once completed, this transit road, reminiscent of the Silk Road, would eventually connect Iran, through Herat, Mazar-e Sharif, and Tajikistan, to China. Iran has signed agreements with Afghanistan, Tajikistan, and Uzbekistan to provide access to international routes for those three landlocked countries.

Iran is also upgrading a tax-free trade route, linking the Oman-based port of Chabahar to the southwestern border post of Malik in Afghanistan, and to Kandahar and Kabul. Once completed, it would greatly diminish the economic importance of the Karachi-Kandahar road, which is Afghanistan's only current roadway to international markets. The road would shorten the distance from the Persian Gulf to Afghanistan by some 700 kilometers; it would offer Afghanistan the right to use Chahbahar with a substantial discount on port fees; and it would also improve living conditions in Baluchestan, one of Iran's poorest provinces. ${ }^{75}$ Iran is additionally allocating substantial resources to upgrade the Malik Bridge over the Helmand River, as well as to upgrade another bridge over the Parian River on the Iran-Afghanistan border. ${ }^{76}$

\section{IRAN, HERAT, AND THE US}

It is in the Herat region that Iran's influence in Afghanistan is most visible. Until 1857, Herat was considered an "integral part" of Iran. ${ }^{77}$ When the British repelled Iranian advances toward Herat, Iran and the UK signed the Treaty of Paris in March of 1857. Although Iran abandoned its historic claim on Herat, it reserved the right, under Article VII, to send forces into Afghanistan "if its frontier is violated."78 Since then, Iran has occasionally sought to keep Herat as a buffer zone. For a few years, Isma'il Khan, the Emir of Herat, helped Iran to realize that goal.

Today, Herat is arguably the most stable and prosperous region in Afghanistan, relatively free from al-Qa'ida and the Taliban. A small industrial city has been con-

72. Global News Wire, Asia Intelligence Wire, March 25, 2005, p. 1.

73. "Iran to Build Bridge to Afghanistan," BBC, Monitoring International Reports from IRNA, January 13, 2002.

74. BBC Persian, February 2, 2006. www.bbc.co.uk/persian/story/2006/02/printable/ 060202_v_afghan_london.html.

75. Khaleej Times, September 24, 2002.

76. $B B C$, January 13, 2002. www.bbc.co.uk/persian/afghanistan/story/2005/07/printable/ 050712_s_industrial_herat.

77. Akbar Hashemi Rafsanjani, Amir Kabir Ya Ghahraman-e Mobareze Ba Astemar [Amir Kabir or the Hero of the Struggle Against Colonialism] (Tehran: Farahnai Press, 1346), p. 377.

78. Hurewitz, J.C., ed. The Middle East and North Africa in World Politics: European Expansion, 1535-1914, Vol. 1 (New Haven: Yale University Press, 1975), pp. 341-343. 
structed, making it the industrial heartland of the country. ${ }^{79}$ Herat's bazaars are reportedly loaded with Iranian products, and the presence of the Iranian Revolutionary Guards is noticeable as well. It is estimated that between " 100 to 400 trucks" and "at least 500 cars" cross Iranian borders to and from Herat daily. They carry a variety of goods to Afghanistan and Pakistan from Iran, as well as from Dubai. ${ }^{80}$ The maverick Isma'il Khan reportedly was earning as much as $\$ 3$ million a month from customs alone,$^{81}$ a huge portion of which is generated from trade with Iran.

The US and Iran have been engaged in a low-key competition in Herat, reminiscent of the Great Game of the $19^{\text {th }}$ Century. Isma'il Khan was apt at playing that game: "both the U.S. and Iran," he said, "want the same thing in Herat that we want: stability, prosperity, and peace." ${ }^{2}$

Isma'il Khan, like many other warlords, developed friendly relations with the US: "According to his [Khan's] security guards, the Americans are providing rudimentary military training to some of Khan's soldiers." ${ }^{13}$ So close was the Khan to the US that he "is permitting Special Forces soldiers to live in a hilltop fortress he built for himself when he was Harat's governor from 1992-1995." ${ }^{84}$

The Khan had excellent relations with Iran as well. He reportedly received Iranian support in his escape from a Taliban prison. Sensitive to Iranian security concerns, he publicly rejected the need for foreign forces in the region: "if they come here and have an everyday presence, it will bring a reaction against them." Just as he denied receiving support from the US, he also denied any military support from Iran: "so the Americans should not worry so much about Iran." ${ }^{85}$ There were, however, reports that Iranian-trained Afghans joined the Khan's forces, which were estimated to be between $50,000-60,000$ strong. ${ }^{86}$

As President Karzai began to centralize authority and instituted a policy to "demobilize, disarm and reintegrate" warlords, Isma'il Khan became one of the policy's first victims. Initially, the Khan was asked to stop using the honorific title "Emir of the Southwest Afghanistan.” Later, in June of 2003, he was forced to hand over \$20 million to the state treasury. ${ }^{87}$ Finally, President Karzai removed Isma 'il Khan as governor of Herat in September of 2004; he was replaced with Sayid Muhmmad Khairkhwa. ${ }^{88}$ This proved to be a setback for Iran, although the decision has had little overall impact on Iran's growing influence in the region. Seyyed Hossein Anvari, the

79. BBC Persian, July 12, 2005. www.bbc.co.uk/persian/afghanistan/story/2005/07/printable/ 050712_s-industrialnl.html.

80. Dietl, "War, Peace and the Warlords," p. 52.

81. Charles Clover, The New York Times, October 9, 2002.

82. Charles Clover, The New York Times, October 9, 2002.

83. David Zucchino, The Los Angeles Times, March 26, 2002.

84. David Zucchino, The Los Angeles Times, March 26, 2002.

85. David Zucchino, The Los Angeles Times, March 26, 2002.

86. Amy Waldman, The New York Times, April 3, 2002.

87. Dietl, "War, Peace and the Warlords," p. 57.

88. See Amin Tarzi, "Is Herrat a Prelude to the End of Afghan Warlordism?" September 26, 2004, www.eurasianet.org.departments/insight/articles/pp092604_pr.shtml. 


\section{$254 \star$ MIDDLE EAST JOURNAL}

new governor, has also developed good relations with Iran. He is, however, no Isma 'il Khan, who now serves in the cabinet as an ineffectual minister of an unimportant ministry.

\section{AHMADINEJAD AND AFGHANISTAN}

After the US invasion of Iraq in 2003, Afghanistan was no longer a top priority for Iran. Once again, Iraq overshadowed Iran's other regional concerns. It is ironic that US policies helped transform Iran into a regional power, by removing the two main security threats to the Islamic Republic: the Taliban and Iraqi President Saddam Husayn. The invasion of Iraq, has, among other things, energized Iraqi Shi'ites. In the short time since the fall of Saddam, Iran has developed exceptionally friendly relations with the Iraqi government and has also created a sophisticated and multilayered "sphere of influence" within Iraq that is much more powerful than the one created in almost three decades of diplomacy in Afghanistan. ${ }^{89}$

As those major strategic transformations were taking place in the region and as Iran's nuclear energy programs and policies became a contentious issue between the West and Iran, Dr. Mahmud Ahmadinejad won the presidency of Iran. He has formulated a "security-centered" and "Islam-centered" foreign policy that in some ways resembles Iran's foreign policy in the 1980s. With his new confrontational approach, Ahmadinejad has substantially increased Iran's isolation. His incendiary and reprehensible comment to "wipe Israel off the map" and his reckless denial of the horror of the Holocaust have generated unnecessary tension in Iran's relations with many countries. His "tit for tat" foreign policy assumes that Iran has given too many concessions to the West, particularly to the United States, without being sufficiently rewarded; that Iran's strategic position in the region and in the Islamic world is favorable while that of the US is not; and that Iran has to formulate a proactive rather than an appeasing foreign policy. More than his predecessors, he is thus likely to use Iran's influence and networks in Afghanistan to counter any offensive against Iran or to enhance Iran's other objectives.

Still, Ahmadinejad's presidency has not, thus far, changed the direction of Iran's policy toward Afghanistan, nor has it lessened Iran's commitment to Afghan reconstruction, as evidenced by Iran's participation in the London Conference on Reconstruction of Afghanistan and its pledge of $\$ 100$ million in 2006. While visiting Afghanistan in December of 2005, Foreign Minister Manouchehr Mattaki echoed the sentiment of many other Iranian leaders: "we are like one soul in two bodies ... we are and will be standing by each other." ${ }^{\circ 0}$

89. Mohsen M. Milani, "Iran, the Status Quo Power," Current History, Vol. 104, No. 678 (January 2005), pp. 30-36.

90. “Afghanistan, Iran,” BBC Worldwide Monitoring, South Asia, December 26, 2005. 
Even before the beginning of the Ahmadinejad presidency, however, Karzai's Pushtunization policy as well as his attempt to centralize authority and diminish the power of forces friendly to Iran had generated some uneasiness in the otherwise amicable relations between Iran and Afghanistan. These tensions have not disappeared. The presence of multinational forces in Afghanistan is, however, one area where the Ahmadinejad Administration is showing a slight policy change. In fact, Ahmadinejad has not only maintained that the presence of the multinational forces is a cause of instability in Afghanistan, he has hinted that Iran's reconstruction projects may be impeded. Thus, Iran has recently demanded a timetable for the withdrawal of multinational forces from Afghanistan. ${ }^{91}$

Iran also is keeping all its options open in Afghanistan and seems to have calculated that the country will not be stabilized anytime soon. The current situation in Iraq has certainly contributed to the overall instability in Afghanistan and thus has increased Iran's ability to foment trouble, if it so chooses. In 2005, the Taliban resurfaced, emboldened by the terrorist activities of their brethren in Iraq against the Coalition forces and Shi' ites. There have been increased occurrences of suicide bombings, roadside bombing, ambushes, and kidnappings in Afghanistan. Some former Taliban and religious extremists have even found new legitimacy as elected members of the Wolesi Jirga. Hekmatyar and his militia have also been reactivated.

Iran's current policy toward Afghanistan is unlikely to change in the near future unless there is a major political change in Afghanistan, Iran is attacked by the United States, its nuclear facilities are struck, or Washington pursues "regime change" as its official policy toward Tehran.

\section{CONCLUSION}

While Iranian foreign policy has certainly been guilty in many cases of adventurism and extremism, Iran's policy toward Afghanistan has contributed more to overall stability and moderation than to instability and extremism. It is rather sobering to quote Barnett R. Rubin, a leading expert on Afghanistan: "the United States [in the 1980s] was indirectly aligned with 'fundamentalists' while Iran courted the moderates." ${ }^{92}$ Iran, like other regional players, added fuel to the bloody Afghan civil war. Under the Taliban, Iran provided support to the same forces that ultimately collaborated with the United States to overthrow the Taliban. Since the liberation of Afghanistan, Iran has followed a moderate policy and has engaged in the reconstruction of that country.

Some aspects of Iran's Afghan policy are clearly antithetical to US interests, but the two countries do share some common objectives. These shared objectives include

91. BBC Persian, January 31, 2006. See: www.bbc.co.uk/persian/afghanistan/stroy/2006/01/printable/060131_he-afghanids.shtml.

92. Barnett R. Rubin, The Fragmentation of Afghanistan (New Haven: Yale University Press, 2002, Second edition), p. 252. 
the establishment of a stable Afghanistan, free from the Taliban and al-Qa'ida; the reconstruction of that country; and the fight against narcotics. In overthrowing the Taliban and forming a new government, the United States and Iran collaborated at some critical junctures, and in the process established a working model of cooperation. They would be well-advised to take a chapter from that previous playbook, should they decide to negotiate in the future.

Although Iran is in a more favorable strategic position in Afghanistan and in Iraq than it has been in decades, Tehran must remember that the United States has virtually encircled Iran with more than 150,000 troops in both Iraq and Afghanistan. It would be very costly, if not impossible, for Iran to solidify its recent gains as a regional power in one of the most important regions of the world without reaching some kind of understanding with the United States, the world's last hyperpower. In the event of a military confrontation with the US over Iran's nuclear programs, Iran could undoubtedly foment trouble for the US in Afghanistan, Iraq, Lebanon, and elsewhere. Ultimately, however, Iran would lose disproportionately more than the US in such a conflict. Only through dialogue and negotiation, rather than angry diatribes and confrontation, will Iran and the United States avoid a devastating clash, whose reverberations could be felt throughout the Middle East. 